\title{
Yeni Kapitalizm ve Türkiye'de Tarım Sektörünün Dönüşümü ${ }^{1}$
}

\author{
ŞERIFE BINGÖL (ib ${ }^{2}$ \\ Başvuru: 28.11.2020; Düzenlenme: 19.12.2020; Kabul: 19.12.2020
}

\section{Giriş}

İnsanların dünyada ilk varlık göstermeye başladıkları andan şimdiye kadar tahmini olarak 200 ile 300 bin yıl arasında bir zaman geçmiştir. İnsanların varlığıyla birlikte en temel canlı ihtiyacı olan beslenme de o tarihlerde ortaya çıkmıştır. İnsanlar tarihte gerçekleşen ilk devrim olan tarım devrimini bulana kadar bu ihtiyacı, avcılık ve toplayıcılık yaparak gidermişlerdir. Tarımın öğrenilmesiyle bugünkü toplum düzenimiz şekillenmeye başlamış, tarım insanlara hem beslenebilmeleri, hem kaynak biriktirmeleri, hem topluma istihdam sağlaması hem de ileride gerçekleşecek olan Sanayi devriminin ihtiyaçlarını karşılama gibi her alanda olumlu katkılar sunmuştur. Fakat 20. yüzyılın sonları itibariyle tarıma verilen önemin azaldığını görmekteyiz. Bu sebepten ötürü bu çalışmada ele alınan konu tarım sektörünün Türkiye özelinde tarihsel bağlamını incelemek ve önemini ortaya koymaktır.

\section{Tezin konusu}

Tezin konusu, Kurumsal İktisat ekolünün hem orijinal hem de yeni versiyonlarını

\footnotetext{
${ }^{1}$ İktisat Anabilim Dalı Yüksek Lisans Tezi, Eskişehir Osmangazi Üniversitesi Sosyal Bilimler Enstitüsü, 2020. Danı̧̧man: Doç. Dr. Oytun Meçik

2 Anadolu Üniversitesi Sosyal Bilimler Enstitüsü Doktora Öğrencisi
}

karşılaştırmalı analizinin yapılmasını, kurumsal yapı ölçüm yöntemlerinin ortaya konulmasını ve bu kapsamda kurumsal yapı ile ekonomik büyüme ilişkisinin çözümlenmesi ve farklı kurum parametrelerinin ekonomi açısından öneminin belirlenmesini kapsar.

\section{Tezin alan içindeki yeri ve önemi, farklı yönleri}

Sanayi devriminden önce bütün dünya ülkelerinde tarım birincil sektör olarak binlerce yıllık önemini koruyarak gelmiştir. Sanayi devriminden sonra da önemini yitirmemiş, sanayiye sağladığı hammadde dolayısıyla önemi artmıştır bile. Fakat 1980'lere geldiğimizde azgelişmiş ve gelişme yolundaki ülkeler için gelişmiş ülkelerin yönetiminde olan uluslararası kurulusların dayatması ve bu ülkelerin küreselleşme sürecine girmeleriyle, tarımda uygulanan ulusal politikalar son bularak tarıma ve çiftçilere verilen destekler tedricen kaldırılmıştır. Gelişmiş ülkelerde tarımda daha bir korumacı politikalara yüz çevrilirken, azgelişmiş ve gelişmekte olan ülkelerde olabildiğince serbestleşme ve yabancıların tarım sektöründe varlık gösterebilmesi için kapılar sonuna kadar açılmıştır. $\mathrm{Bu}$ kapıları kapatma yolunda çok ufak bir katkı sağlaması için seçilen bu çalışmada öncelikle üretim ilişkilerinin tarihi ele alınmış ve daha sonra 1980'lerde küreselleşme olarak da bildiğimiz 'yeni kapitalizm' kav- 
ramı irdelenmiştir. Türkiye tarım sektörünün iyi anlaşlabilmesi için köklerine uzanılmış ve Osmanlı'daki tarım yapısına kısaca değinilmiştir. Türkiye tarım sektörü ise dönemlendirmelere ayrılarak incelenmiş, uygulanan politikalar ve tarımda sağlanan gelişmeler gerek doküman analizlerinden gerekse de yerli ve uluslararası veri tabanlarından elde edilen verilerle sunulmuştur.

\section{Tezin önemi}

$\mathrm{Bu}$ çalışma, literatürde yer alan pek çok çalışma gibi tarımın önemini vurgulamak üzere hazırlanmıştır. Üretim süreçlerini ve ilişkilerini değiştiren ve dönüştüren yeni kapitalizmin tarım sektörü üzerindeki etkileri analiz edilerek Türkiye ekonomisine olan makro etkisi verilmeye çalışllmıştır.

\section{Tezin kısa özeti}

Üretim ilişkileri tarihine baktığımızda ve kabaca bir kronolojik sıralama yaptı̆̆ımızda ilk üretim biçimi olarak karşımıza avcılık ve toplayıcılık olan ilkel üretim tarzı çıkmaktadır. Tarım Devriminin başlamasıyla avcılık toplayıcılık yerini ekip biçmeye bırakmıs ve insanlar yerleşik hayata geçerek bugünkü toplumun ilk şekilleri oluşmuştur. Tarımın en büyük katkısı uzun vadeli gıda üretimini sağlamasıdır ve bu katkı insanlara boş zaman sağlayarak insanların yeni şeyler keşfetmesine ve kendilerini geliştirebilmelerine imkan sağlamıştır. Yeni iş aletleri ortaya çıkmış, el zanaatları gelişerek insanların el becerilerinin ve zihinsel olarak da gelişmesini sağlamıştır. İlk toplumların gelişmesi zamanla özel mülkiyeti de doğurmuş ve ikinci mülkiyet biçimi olan komün mülkiyeti yanında özel mülkiyet de yer almıştır. Bu toplumda iki sınıf vardır: özgür yurttaşlar ile köleler. Üretim köleler üzerinden gerçekleşmektedir. Üretimin sadece köleler üzerinden yürütülmesi bir süre sonra köle arzını artıramayan imparatorluklarda bir krize yol açmış ve kölelerin tam özgür yurttaş olarak sayılmadığı fakat kısmi de olsa özgürlüklerini ele aldıkları bir biçime dönüşerek üçüncü mülkiyet tarzı olan feodal üretim tarzının doğmasına neden olmuştur. Feodal üretim tarzında ise serfler ile lordlar arasındaki ilişki, ticaretin gelişerek bir burjuva sınıfının doğması, Fransız Devriminin etkisi ve son olarak da gelişen sanayi ile son bulmuştur. Daha sonra ortaya çıan üretim biçimi ise kapitalist üretim tarzıdır. Kapitalist üretim tarzının ilk dönemi sayılacak olan $16-18$ yy arasında manifaktür yani iş bölümüne dayalı el işi üretim tarzıdır. $\mathrm{Bu}$ üretim tarzında emek süreci parçalara ayrılmış ve küçük üreticiler parça iş̧̧ilere dönüştürülmüştür. 18. yüzyılda Sanayi Devrimiyle birlikte artık üretim büyük fabrikalarda yapılmaya başlanarak manifaktürde kullanılan kol emeğinin yerini makineler almış ve insanlar makinelerin birer uzantısı haline getirilerek vasıfsızlaştırılmıştır. Fordist sistem 1960'lara kadar sorunsuz devam etmiş fakat 1970'lerde sistem kendini yenileyemez yeniden üretemez hale gelince çökmüştür. Kapitalist sistem 197'lerde yeni bir evreye girmiştir. Bu yeni evre kapitalizmin işleyiş başka bir formda devamı anlamına gelmektedir. Bu form literatürde yeni kapitalizm, neo kapitalizm, esnek kapitalizm, küreselleşme, örgütsüz ya da disorganize kapitalizm gibi adlandırmalar alır. Esnek üretim tarzı olarak da niteleyebileceğimiz bu üretim tarzının en net söylemleri esnekleşme, serbestleşme, sermayenin küresel ölçekte dolaşımı, finansallaşma, küçük ölçekli üretim gibi. Burada belirtilmesi gereken nokta dünyanın tek kutuplu olmadığ 1 gerçeğidir. Dünya ülkeleri farklı gelişmişlik düzeylerine sahip oldukları için bu 'yeni kapitalizm' adı altında az gelişmiş ve gelişmekte olan ülkelere dayatılan politikalar gelişmekte olan ülkelerin yararına olumlu sonuçlar, o politikaları uygulayan ülkeler için ise zararına olumsuz sonuçları gün geçtikçe daha da gün yüzüne çıkarmaktadır. Bu olumsuzluklardan en çok etkilenen sektör ise tarım sektörüdür. Bu çalışmadaki amaç bu politikaların olumsuz yansımalarını göstermektir. 


\section{Tezde işlenen konular}

$\mathrm{Bu}$ çalışma 3 bölümden oluşmaktadır. Birinci bölümde yeni kapitalizm ve üretim ilişkilerinin dönüşümü konularma ayrılmıştır. Yeni kapitalizm kavramından önce, kapitalizm kavramı tarihsel bağlamı içinde incelenmiş ve kendinden önceki üretim biçimleri anlatılarak günümüzde geçerli olan yeni kapitalizm kavramına bağlanmıştır.

İkinci bölümde ise Türkiye'nin tarımsal geçmişi belirli dönemlendirmeler yapılarak irdelenmiş, bu dönemlerde tarımda gerçekleşen gelişmeler ve uygulanan politikalar ele alınmıştır. Bu bağlamda yeni kapitalizmin tarım sektörüne olan etkileri ve tarımda yaşanan dönüşüm anlatılmıştır. Üçüncü bölümde ise tarımda yaşanan dönüşümün Türkiye ekonomisine olan etkileri incelenmiştir.

\section{Tezin Hedef Kitlesi}

$\mathrm{Bu}$ çalışmada ele alınan kuramsal konular özelde iktisat alanında çalışan teorisyenler, araştırmacılar ve öğrenciler iken genelde ise tarım, bütün toplumu etkileyen ve ilgilendiren bir konu olduğu için bu konuya ilgili olan herkesin takdirine sunulmuştur. 